In conclusion, I would reiterate that calcium metabolism is a highly complex problem that is far from being solved. It is affected in many ways but, whatever a diet may or may not contain provided it contains an adequate amount of calcium, it appears from the evidence we have that in man the only important single factor is vitamin $\mathrm{D}$.

\title{
REFERENCES
}

\author{
Bruce, H. M. \& Callow, R. K. (1934). Biochem. F. 28, 517. \\ Evans, C. L. (1941). Principles of Human Physiology, 8th ed. London: J. and A. Churchill. \\ Harrison, D. C. \& Mellanby, E. (1939). Biochem. $₹ .33,1660$. \\ Irving, J. T. (1944-5). F. Physiol. 103, 9. \\ Irving, J. T. (1957). Calcium Metabolism, p. I05. London: Methuen \& Co. Ltd. \\ King, C. G. (1949). F. Amer. diet. Ass. 25, 109. \\ Krebs, H. A. \& Mellanby, K. (1943). Biochem. Y. 37, 466 . \\ Leitch, I. (1936-7). Nutr. Abstr. Rev. 6, 553. \\ McCance, R. A. \& Widdowson, E. M. (1942-3). F. Physiol. 1or, 350. \\ McGowan, J. P., Cunningham, I. J. \& Auchinachie, D. W. (193 I). Biochem. F. 25, 1295. \\ Massler, M. \& Schour, I. (1946). Amer. F. Orthodont. 32, 495. \\ Mellanby, E. (г921). Spec. Rep. Ser. med. Res. Coun., Lond., no. 6r. \\ Mellanby, E. (1944). Proc. roy. Soc. B, 132, 28. \\ Mellanby, H. (1952). Arch. Dis. Childh. 27, r33. \\ Mellanby, M. (1929). Spec. Rep. Ser. med. Res. Coun., Lond., no. 140. \\ Mellanby, M. \& Coumoulos, H. (1946). Brit. med. F. ii, 565. \\ Mellanby, M., Coumoulos, H. \& Kelley, M. (1957). Brit. med. $\mathcal{F}$. ii, 318 . \\ Mellanby, M. \& Mellanby, H. (1954). Brit. med. J. ii, 944. \\ Sherman, H. C. (1920). F. biol. Chem. 44, 21. \\ Schour, I. \& Massler, M. (1945a). F. Amer. dent. Ass. 32, 7 I4. \\ Schour, I. \& Massler, M. (1945b). 7. Amer. dent. Ass. 32, 871 . \\ Wishart, G. M. (1938). Brit. dent. F. 64, r29. \\ Wolbach, S. B. \& Howe, P. R. (1926). Arch. Path. (Lab. Med.) r, r.
}

\section{Teeth in earlier human populations}

\section{By D. R. Brothwell, Duckworth Laboratory, Cambridge}

It is particularly fortunate, at least in human beings, that the teeth are situated in the skull. The archaeologist of the past was far from particular about what was thrown away, provided it did not yield one of the standard measurements, which has resulted in many post-cranial remains finding their way into the museum dustbins of the world. However, the teeth remained, and odontological aspects of anthropology are now beginning to stimulate considerable interest.

The purpose of my study has been to try to ascertain the influence of food on the oral conditions of earlier man. There are, of course, numerous difficulties, especially in the statistical treatment of results. Caution must be taken against any possible selective bias in a cranial series (Krogman, I938), and mean ages of groups should be similar (Stewart, r93 I ; Krogman, r935). Where possible I have guarded against inaccuracies from these sources. Although in some groups there are slight differences between the sexes in the frequency of dental disease, it was thought sufficient to combine the data in this analysis. With periodontal disease, skull material is likely 
to give an underestimate of incidence because changes are detectable only when they affect the alveoli (Klatsky \& Fisher, 1953). Cultural factors must also be borne in mind, as interference with the teeth for surgical and hygienic purposes was practised by ancient as well as modern peoples. In the ancient Mesopotamian civilizations, for example, extractions were undertaken (Sigerist, 195 I), and Aristotle also mentions dental extraction of loose teeth and the removal of deposits of salivary calculus (Densham, 1909). Stick tooth brushes and ash toothpaste are not recent inventions. Thus we cannot always be sure, in studying earlier groups, that man himself has not influenced his oral condition, and even apes seem capable of wielding the toothpick.

It has become clear in recent years that we can no longer regard dental disease as a phenomenon of post-Palaeolithic man, and indeed it might always have affected the Hominidae. The fact that caries and periodontal disease are occasionally found in modern wild anthropoid apes (Colyer, 1936; Schultz, I956), shows that, in the higher primates, they are not exclusive to man's oral environment.

From the early Pleistocene, evidence of caries is to be found in two widely separated hominid groups, both probably contemporary some half-a-million years ago. The first is the Australopithecine apes of South Africa, of particular interest in that their semi-upright posture had enabled them to move away from a purely arboreal existence in search of what was probably a more omnivorous diet. Probably they lived in a fairly arid climate with distinct rainy periods, their habitat being undulating plains with few trees. In such an environment, seasonal malnutrition could well have occurred, and the teeth support this hypothesis, for Robinson (1952) found that of forty-seven isolated teeth of one genus, Paranthropus crassidens, $28 \%$ showed signs of hypoplastic pitting. He also established the presence of caries in two molars of $P$. crassidens, both being associated with hypoplasia, and Clements (1956) found caries in another variant, Telanthropus. We see then what appears to be a very early example of a relationship between environment, especially nutritional, faulty formation of dental enamel and caries. The second group is Java fossil man, Pithecanthropus, and although no intense study has been made of his oral health, signs of caries have been affirmed by Brodrick (1948).

In middle-Pleistocene times, the Neanderthal form of man, who lived perhaps some 150,000 years ago, shows evidence of dental disease. Sognnaes (1956) examined a number of Neanderthal teeth from Mount Carmel, Palestine, and found that these, as well as specimens from later prehistoric man, showed faulty micro-structure in most of the samples. A cervical caries cavity has been noted (Sognnaes, $195^{6}$ ) as well as abscesses and periodontal disease, the latter condition being clearly present in a number of Neanderthal specimens (for example La Chapelle, Tabun I and Skhul V). Recently I examined a number of Neanderthal and later prehistoric skulls and found that in some specimens the macro-structure of the tooth also displayed enamel defects. Neanderthal dental attrition was no greater than in Anglo-Saxon teeth, even in the children of these groups, although definite abrasive scratches appear to be present on two or three front teeth in the Mount Carmel Tabun I skull, pointing to a fairly coarse abrasive being present in the food. 
Upper Palaeolithic man also furnishes evidence of varying dental health. Perhaps the most surprising specimen is that of the Rhodesian skull, representing a massive Neanderthaloid form. Eleven of thirteen teeth display caries (fifteen cavities) and there were at least four abscesses at the roots. Periodontal disease was also present to a minor degree but no hypoplasia was noted. The reason for Rhodesian man's caries is difficult to suggest although extreme attrition can be ruled out. As most of the cavities do not appear to have begun occlusally, fermentation of food debris between the teeth may have been the cause. Perhaps, like the modern Bushman, he sought natural sugar, but supported a larger population of putrefactive bacteria. Clearly, whether we suggest as a cause a greed for honey, too much cooking or contact with a superior culture, diet is the predominant factor. Paradoxically, it is in some of the modern South African groups that we meet extremely good dental health even though they have a high-carbohydrate diet.

In the later part of the Palaeolithic, more cases of oral disease are to be found. Krogman (1938) notes carious teeth in Aurignacian crania, buried some 80,000 years ago, and Vallois (1936) mentions the occurrence of caries in two crania from French Solutrean deposits. Of the Mesolithic period, about Io,000 years ago, ten of twentyfour skulls from Ofnet, Bavaria, displayed carious teeth. Cavities were present in $3.8 \%$ of the Mesolithic teeth from Teviec, and there is some evidence of the disease in crania from Mugem in Portugal (Vallois, 1936). As the number of cases is small, the percentage frequencies are therefore only crudely indicative of the caries picture. Probably no great difference in dental disease was evident between Mesolithic and Upper Palaeolithic man, and although technologically the former was slightly superior to the latter his food was of a similar nature, the economy being still based on hunting, fishing and gathering. Indeed, this type of economy would seem to reduce susceptibility to caries, as Goldstein ( 1948 ) has found in early Texas Indian material. It is at the beginning of the so-called Neolithic revolution that great steps forward in the economic and social structure are to be seen. Pottery was produced, plots were cultivated with cereals, and domestic flocks and herds grazed. Important too is the probable rapid increase in population and the development of large towns. A coarse bread was no doubt generally made, and cooked foods became a more normal part of the diet. As the cultural picture is somewhat complex in the European area from then on, the study will be restricted as far as possible to British archaeological material.

In Figs. I and 2 caries and tooth loss are plotted for British Neolithic and later series, as well as for two comparative groups from other countries. In the British series, 7000 teeth were examined for caries, and over I I,000 in assessing tooth loss. The Greek and French frequencies were obtained from published values representing for each over 4000 teeth (Angel, 1944; Pales, 1947a,b). The two frequency graphs show in rough but simple form the pattern of caries and periodontal disease in earlier populations, the mean age group for all being young adult.

Both in Britain and France the Neolithic caries frequency was quite low, but it was not universally so, for in Greece we see $12 \%$ of the teeth affected. During the British Bronze Age, both caries and pre-mortem tooth loss were less than in the Neolithic, 


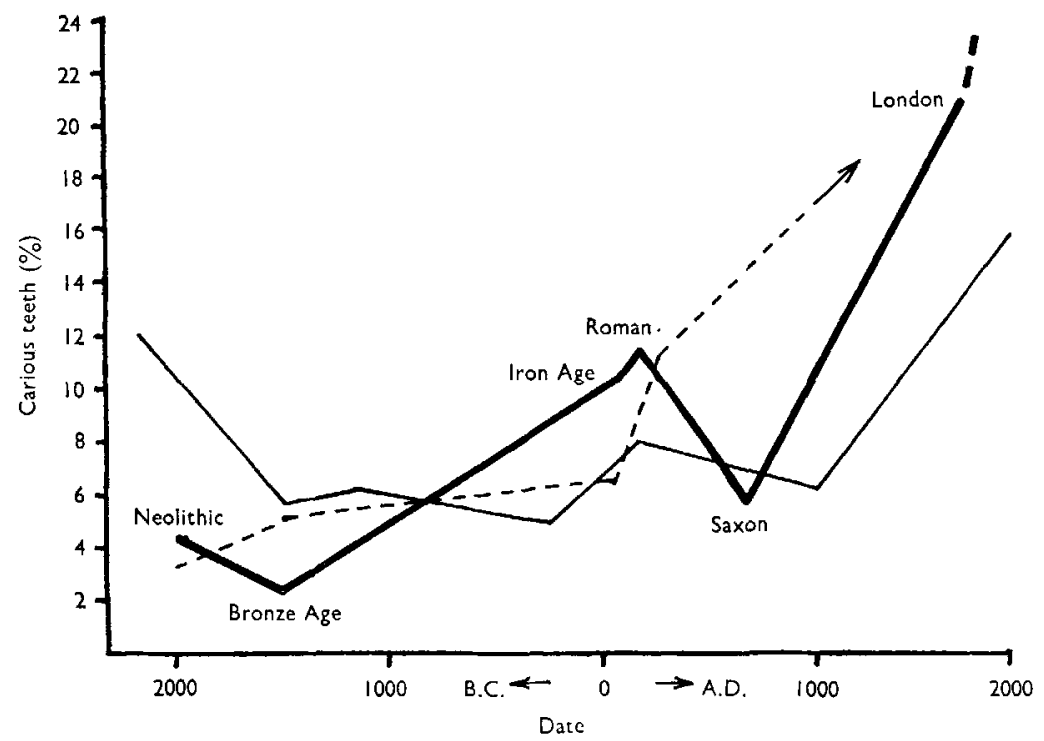

Fig. I. Caries frequencies in different Ages in groups, mainly of young adults of both sexes; in Britain, Greece and France. —, Britain; —_, Greece; - - - , France.

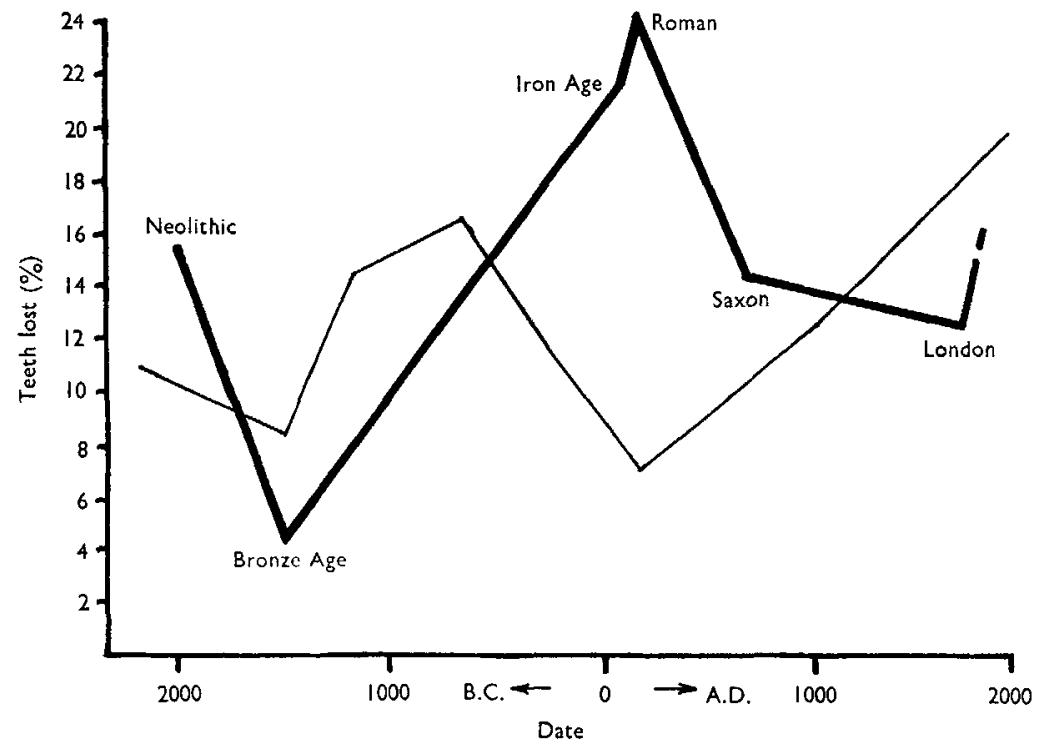

Fig. 2. Tooth loss due to disease in British and Greek populations in different Ages.

British; $\longrightarrow$, Greek.

and this drop is also seen in Greece. It is at the end of this period that a rapid decrease in oral health is to be observed in Britain, continuing from the Iron Age into Roman times. In Greece, however, caries increased in the Roman period, whereas loss of teeth declined noticeably. Clearly, these two areas show that it was not the advent of the Roman culture and the considerable urbanization which took place then that influenced the increase in dental disease, but that other factors had come into play long before. With the Anglo-Saxon invasions another considerable decline in both 
frequencies took place, followed by an increase in caries incidence until by the 17 th-1 8 th centuries about $20 \%$ of the teeth were affected. However, as regards tooth loss, the next 800 years after the Saxon period saw yet another decrease in frequency. In France and Greece also, there was a steady increase in caries after about the 12 th century. These percentages need not, of course, represent the population of a whole country at any given time, especially as there were often cultural backwaters, but they do show the general trend.

It may be noted here that in a large proportion of pre-mediaeval British material, caries takes the form of cervical cavities, and there is some evidence to suggest that the later increase in caries frequency was not so much due to a higher number of these cavities as to more occlusal cavities, which occur because the fissure patterns are not eliminated by attrition, as they would have been in earlier times.

Various degrees of hypoplasia were noted in early British skulls, particularly of post-Bronze-Age date, and $58 \%$ of those examined showed the defect in more than one tooth. Mostly this was no more than a superficial enamel defect and, although there is no definite association between it and caries (Mellanby, 1932), it seems evident that any surface irregularity, whether in the form of minor ridging or fissures, ensures a safer mooring for the bacterial plaque against friction by food.

Periodontal disease was evident in ancient man even though the mean age was probably no more than about $30-35$ years. Of a sample numbering 130 skulls, in age dating between Neolithic and Saxon periods, at least $74 \%$ showed some degree of alveolar recession. In some cases of extreme wear it is no doubt the main cause, but clearly there are other factors, food impaction doubtless being a major one. Calculus is very common in pre-mediaeval skulls and, as Cross (1958) points out, it plays an important role in the production of periodontal disease. As in the modern Egyptian labourers (Dawson, 1948) who have a periodontal disease frequency of $97 \%$, a lowered tissue resistance due to faulty nutrition was probably a principal factor, and Noble (1956) finds that even in such a late group as the Saxons there is evidence of seasonal dietary disturbances.

An interpretation of the findings concerning the oral health of early man is not easy, for even in the Stone Age, a number of variables were at work, though physical and biochemical aspects of diet were clearly associated with most of them.

The ability to contract caries and periodontal disease may always have been with man and his fossil predecessors, although there is no reason why types, degree of pathogenicity, and population sizes of oral bacteria should not have changed during the last million years. The swing from a hunting and collecting economy to one of high cereal consumption could have affected not only the general oral environment but jaw and dental development as well. The development of cereal crops in Neolithic times also resulted in considerable deforestation, which has certainly led to soil impoverishment in some areas where caries is now so common.

Population increase and its concentration may also have been a contributive factor (Mitchell, 1933; Angel, 1944) even before mediaeval times, and may have led to malnutrition, particularly during the winter months when food resources were limited. 
The rough nature of the food consumed by earlier man, especially before Neolithic times, helped to dislodge food particles as well as stimulating vigorous mastication. It also seems likely that, with harder food, the actual time spent daily in chewing would be greater in these earlier peoples. If Neumann \& DiSalvo (1957) are right in suggesting that chewing compression changes the enamel structure and increases resistance to caries, then their view may also help to explain early man's relative immunity to caries.

The last straw, as far as British populations are concerned, was the introduction of sugar in the I2th century, and refined white flour in the Igth. Indeed, we are led to the painful conclusion that if we had been content to chip flints and keep away from foreign trade our teeth would have been healthier for it.

I am much indebted to Dr N. A. Barnicot for criticisms and suggestions, also to Dr K. P. Oakley of the British Museum (Natural History) for helpful suggestions and permission to examine original Palaeolithic material and later skulls. Grateful thanks are also due to Dr J. C. Trevor, who in the past has given me access to the Duckworth Laboratory skull material. Lastly, I wish to thank my wife for her general help.

\section{REFERENCES}

Angel, J. L. (1944). Hum. Biol. 16, 283.

Brodrick, A. H. (1948). Early Man. London: Hutchinson.

Clements, A. J. (1956). Brit. dent. Y. I02, 4.

Colyer, F. (1936). Variations and Diseases of the Teeth of Animals. London: Bale \& Danielsson.

Cross, W. G. (1958). Int. dent. F., Lond., 8, 333 .

Dawson, C. (1948). F. dent. Res. 27, 5 I 2.

Densham, A. (1909). Proc. R. Soc. Med. odont. Sect. 2, 7 I.

Goldstein, M. S. (1948). Amer. F. phys. Anthrop. 6, 63.

Klatsky, M. \& Fisher, R. L. (1953). The Human Masticatory Apparatus. London: Henry Kimpton.

Krogman, W. M. (I935). Amer. F. phys. Anthrop. 20, 43.

Krogman, W. M. (1938), Z. Rassenk. 7, 4I.

Mellanby, M. (1932). Brit. med. J. ii, 749.

Mitchell, H. M. (1933). Hum. Biol. 5, 274.

Neumann, H. H. \& DiSalvo, N. A. (I957). F. dent. Res. 36, 286.

Noble, H. W. (1956). Archaeol. Cant. 70, 113.

Pales, L. (1947a). Anthropologie, Paris, 5r, 220.

Pales, L. (1947b). Anthropologie, Paris, 5I, 416.

Robinson, J. T. (1952). F. dent. Ass. S. Afr. 7, 102.

Schultz, A. H. (1956). In Primatologia, Vol. I, p. 965. [H. Hofer, A. H. Schultz and D. Starck, editors.] Basel: S. Karger.

Sigerist, H. E. (r95I). A History of Medicine: I. Primitive and Archaic Medicine. New York: Oxford University Press.

Sognnaes, R. F. (1956). Amer. F. phys. Anthrop. 32, 547.

Stewart, T. D. (1931). Amer. F. phys. Anthrop. 15, 315.

Vallois, H. V. (1936). Anthropologie, Paris, 46, 201.

The following references, not mentioned in the text, contain further relevant information:

Ayllon, P. (1958). Int. dent. $\mathscr{7} .$, Lond., 8, 332.

Belding, P. H. \& Belding, L. J. (I948). Y. dent. Res. $27,480$.

Bödecker, C. F. (1930). F. dent. Res. ro, 313.

Bramstedt, F. (1958). Int. dent. F., Lond., 8, 179.

Clements, A. J. (I958). Brit. dent. F. I04, I 5.

Dick, J. L. (1915). Proc. R. Soc. Med. Dis. Child. Sect. 9, 83. 
Dirks, O. B. (1958). Int. dent. F., Lond., 8, г82.

Driak, F. (1956). Int. dent. F., Lond., 6, 537.

Dustin, J. P. (1958). Int. dent. F., Lond., 8, 186.

Hellman, M. (1925). Dent. Cosmos, 67, 185.

Humphreys, H. (1951). Brit. dent. F. 91, 216.

Keith, A. (1929). The Antiquity of Man, and ed. Vols, I and 2. London: Williams and Norgate.

McCown, T. D. \& Keith, A. (1939). The Stone Age of Mount Karmel. Oxford: Clarendon Press.

Macdonald, J. B. (1958). Int. dent. F., Lond., 8, I78.

Mummery, J. R. (1890a). Trans. odont. Soc., Lond., 2, 7.

Mummery, J. R. (1890b). Trans. odont. Soc., Lond., 2, 27.

Neumann, H. H. \& DiSalvo, N. A. (1957). Northw. Med., Seattle, p. 706.

Pedersen, P. O. (1952). Dent. Res. 72, s.70.

Ruffer, M. A. (r920). Amer. F. phys. Anthrop. 3, 335 .

Thielemann, K. (1958). Int. dent. F., Lond., 8, 342 .

\section{The histochemistry of human tooth development}

\section{By A. R. Ten Cate,* Department of Dental Anatomy and Dental Pathology, The \\ London Hospital Medical College, University of London}

Histochemical techniques are aimed at elucidating the chemistry of cells and tissues. Since it has been suggested (Landauer, 1954) that developmental defects are caused by an intervention in metabolic events at a cellular level, an understanding of the histochemistry of tooth development is of importance if the effects of nutritional disturbances on this process of development are to be understood.

The first signs of human tooth development occur 6 weeks after fertilization (I I mm crown-rump embryo), when an epithelial thickening arises in the region of the future dental arch. This is the forerunner of the ectodermal component of the teeth and is termed the dental lamina. The cells of the oral epithelium, from which the dental lamina arises, contain deposits of glycogen which serve as a store of energy.

Proliferation occurs at ten points in the dental lamina corresponding to the future position of the primary teeth; each resultant swelling is known as a tooth bud. As the tooth buds increase in size they proliferate into the underlying mesoderm and, by a process of differential growth, attain the cap stage of development, characterized by a shallow invagination on the deep surface of the bud (Pl. I $a$ ). As a result of the organizing influence of the epithelium, the mesoderm enclosed by the invaginated portion of the tooth bud proliferates and condenses to form the dental papilla, the formative organ of the dentine and the primordium of the pulp. The ectodermal portion of the tooth is known as the enamel organ. During the proliferative phase the glycogen content of the ectodermal cells diminishes. This diminution is due either to utilization of glycogen by anaerobic metabolism as proliferation proceeds or to the fact that, as cells penetrate deeper into the underlying mesoderm, they come into association with an improved vascular supply and the necessity for glycogen accumulation no longer exists.

\footnotetext{
* The histochemical findings on human tooth development presented in this paper form part of the work done for the fulfilment of the requirements for the Degree of Doctor of Philosophy of the University of London.
}

18 (1) 6 